\title{
Prevalence of Microbes on Hands of Health Care Workers in Surgical Intensive Care Unit at Tertiary Care Hospital
}

\author{
Ranweer $^{1 *}$, Geeta Parihar ${ }^{1}$, Nirwan Prem Singh ${ }^{2}$ and Chandwani Jyotsna ${ }^{1}$ \\ ${ }^{1}$ Department of Microbiology, Jawaharlal Nehru Medical College, Ajmer (Raj.), India \\ ${ }^{2}$ Department of Microbiology, American international institute of medical sciences, \\ Udaipur, (Raj.), India
}

*Corresponding author

\begin{tabular}{|c|}
\hline Keywords \\
\hline $\begin{array}{l}\text { Microbes, Hand } \\
\text { wash, Health care } \\
\text { workers, Intevsive } \\
\text { care unit }\end{array}$ \\
\hline Article Info \\
\hline $\begin{array}{l}\text { Accepted: } \\
\text { 10 February } 2019 \\
\text { Available Online: } \\
10 \text { March } 2019\end{array}$ \\
\hline
\end{tabular}

\section{A B S T R A C T}

\section{Introduction}

Health care associated pathogens can be recovered from frequently colonized areas of normal, intact patient skin. About 5-10\% patients admitted to acute care hospitals can acquire an infection during hospital stay and it adds to the morbidity, mortality and costs that would be expected from the patient's underlying disease alone, so WHO contributes to the patient safety programme with safety challenge "Clean Care is Safer Care" for 
prevention of HAI. ${ }^{(1)}$ The Patients admitted to the ward if they were particularly susceptible to infection, were carrying with highly resistant strains such as Staphylococcus aureus, was isolated usually in small numbers from cotton gowns, plastic aprons and nurses uniforms. ${ }^{(2)} \mathrm{A}$ hand-disinfection system using an antimicrobial agent (chlorhexidine) reduces the rate of nosocomial infections more effectively than one using alcohol and soap. ${ }^{(3)}$

The Association for Professionals in Infection Control (APIC) has issued guidelines for hand washing practices. ${ }^{(4)}$ When taking care of patients infected with virulent or epidemiologically important microorganisms, HCWs should consider using antiseptics for hand washing rather than soap and water, especially in intensive care units. Antiseptics that have a residual effect will continue to suppress microbial growth well after hand washing, but antiseptics should not be used as a substitute for adequate hand washing. (5) Hand washing with chlorhexidine reduces 98$100 \%$ in bacterial counts, and the introduction of routine hand washing by staff before moving from one patient to the next was associated with a significant and sustained reduction in the number of Klebsiella spp. infection. ${ }^{(6)}$ At Surgical Site Infection due to microbial contamination of the wound that can be prevented by use of specific antiseptic agents and hand washing of surgical staff. ${ }^{(7)}$ Alcohol hand rubs are less irritant and are easily accessible, using alcohol hand rub increases compliance rates by $25 \%$ thereby reducing nosocomial infection. ${ }^{(8)}$

\section{Materials and Methods}

This study was conducted in the Department of Microbiology, J.L.N. Medical College and Associated Group of Hospitals, Ajmer (Raj) over a period of 18 months from July 2010 to Dec. 2011. Before taking samples hand washing techniques were explained. Then 100 samples were taken from $25 \mathrm{HCW}$ and 100 samples were taken from 25 Non HCWs on blood agar, MacConkey agar and Nutrient agar before and after hand wash. Samples were taken at random times with respect to the time of last hand wash or patient care by Direct impression for 5 seconds of the fingers and part of the palm of study and control subjects was taken onto Blood Agar, Nutrient Agar and MacConkey Agar plates from the left and right hands. For after hand wash samples, subjects and controls were requested to wash their hands with non perfumed soap/ alcohol hand rubs provided in the SICU and after the hands were air-dried, then sample taken onto fresh plates as before. The culture plates are transported to and from the laboratory in a sterilized air tight container then after sampling The test settle plates and the control plates are collected and transported in the thermocol box/container to the laboratory. Then plates are incubated overnight for a period of $18-36$ hours at $37{ }^{\circ} \mathrm{C}$. Next day each plate showing bacterial colonies and identified by culture characteristics, gram's staining, and biochemical reactions using the standard procedures and modified Kirby Bauer method for sensitivity. ${ }^{(9)}$ (as per CLSI guidelines) from the pure isolates.

\section{Study subjects}

25 S.I.C.U. Health Care Workers clinicians, anaesthesiologists, nurses, ward attendants, technicians and safai karamcharie were included in this study. 25 Controls comprising of persons not involved in patient care in the S.I.C.U. were taken.

\section{Study design}

\section{Observational type Study type}

\section{Prospective}

Inclusion criteria: 25 S.I.C.U. Health Care Workers clinicians, anaesthesiologists, nurses, 
ward attendants, technicians and safai karamchari were included.

\section{Results and Discussion}

Out of $25 \mathrm{HCWs}, 26$ isolates were detected from $16 \mathrm{HCWs}$ and most common pathogen were coagulase positive Staph aureus (15) out of these $6(40 \%)$ from left hand and $9(60 \%)$ from right hand, from 11(44\%) HCWs including 7 MRSA (7\%) from all the hands samples. Another common pathogen were Klebsiella pneumoniae10 out of these $6(60 \%)$ from left hand, 4(40\%) from right hand isolates from $7(28 \%)$ HCWs and Least number of pathogen was E. coli 1 isolated $1(100 \%)$ from left hand from $1(4 \%)$ HCWs.

All the pathogens were isolated before hand wash and No pathogens isolated after the hand wash and samples from Non HCWs. However $3(12 \%) \mathrm{HCW}$ in which 2 ward attendants having S. aureus and Klebsiella pneumoniae and 1 nurse having E. coli and S aureus were having multiple pathogens. Staphylococci aureus sensitive to Cefoxitine Erythromycin, Tetracycline Amoxyclave, Llinezolid (100\%), Vancomycin (100\%), Netilmicin (100\%), Clindamycin Gentamicin and resistant to Cotrimoxazole( $100 \%$ ) Oxacillin, Ampicillin and Quinupristin (46.7\%).

The four S.aureus sps (MRSA) isolates had identical drug resistance profiles being resistant to Oxacillin, Penicillin, Cephalexin, Gentamicin, Ciprofloxacin, Erythromycin, Ampicillin and Amoxycillin/Clavulanic acid. They were sensitive to Clindamycin, Vancomycin, Linezolid, Tetracycline and Netilmicin. Klebsiella pneumoniae were resistant to all antibiotic except Imipenem and, Netilmicin and Chloramphenicol. E. coli was sensitive to all antibiotics except Ampicillin, Tobramycin, Cotrimoxazole, Cefoperazone, Cefoxitin and Tetracycline.
The Healthcare personals may often spread the bacterial resistance through their routine and innocuous work, especially in I.C.U. and wards. In I.C.U. $82.5 \%$ surgical wards and $24.7 \%$ patients file were found to be contaminated with potentially and other multiply resistant bacteria mainly pseudomonas aeruginosa and then Staphylococci aureus (1\% MRSA). ${ }^{(10)}$

In this study $7 \%$ MRSA were isolated similar to study done by Gaspard et al., (11) that observed that Methicillin resistant Staphylococcus aureus (MRSA) and other multiple resistant bacteria are frequently isolated in long-term care facilities staff clothing and pockets and these samples showed a high level of MRSA contamination. Wearing plastic aprons and managing pocket contents improved the contamination rate and this is highlight the continued importance of hand hygiene, since staff have frequent contaminates with their uniforms and could potentially contaminate their hands before care. ${ }^{(11)}$

In this study Most common isolates was total $15 \%$ Staphylococci aureus total 7\% \% Staphylococci aureus (MRAS), 10\% Klebsiella pneumoniae and $1 \%$ E. coli were isolated, however Wong D, et al., ${ }^{(12)}$ reported $S$. aureus were on the doctors coats of individuals and were more likely to be isolated from the cuff and pocket.S. aureus was isolated was most common isolates $(25 \%)$.

In the present study total $7 \% \%$ Staphylococci aureus (MRAS) and 1\% E. coli were isolated that was similar to study done by A.R.GPUTA et al., ${ }^{(13)}$ they observed in ICU staff, 97 specimens were collected out of which 11 $(11.34 \%)$ showed the growth of MRSA and 3 (3.09\%) showed the growth of Gram negative bacilli. In the second phase of the study, barrier nursing precautions were introduced like, wearing of protective caps, masks, 
changing into clean linen instead of the normal uniform, and frequent hand washing before and after attending a patient. There was a significant reduction of MRSA growth in the ICU environment, (4.81\%), and Gram negative bacilli to $1.2 \%$, and the patient sites (MRSA 4.86\%), however the staff carrier status did not show any change in the MRSA growth (13.4\%) (Table 1-4).

Table.1 No. of pathogens isolated from right and left hand of HCWs

\begin{tabular}{|c|c|c|c|c|c|c|c|c|}
\hline \multirow[t]{3}{*}{ Name of Isolates } & \multicolumn{4}{|c|}{$\mathrm{HCWs}$} & \multicolumn{4}{|c|}{ Non-HCWs } \\
\hline & \multicolumn{2}{|c|}{$\begin{array}{l}\text { LEFT HAND } \\
\quad(\mathrm{n}=25)\end{array}$} & \multicolumn{2}{|c|}{$\begin{array}{l}\text { RIGHT HAND } \\
\quad(\mathrm{n}=25)\end{array}$} & \multicolumn{2}{|c|}{$\begin{array}{l}\text { LEFT HAND } \\
\quad(\mathrm{n}=25)\end{array}$} & \multicolumn{2}{|c|}{$\begin{array}{l}\text { RIGHT HAND } \\
(\mathrm{n}=25)\end{array}$} \\
\hline & $\begin{array}{l}\text { BHW } \\
(\%)\end{array}$ & $\begin{array}{l}\text { AHW } \\
(\%)\end{array}$ & $\begin{array}{l}\text { BHW } \\
(\%)\end{array}$ & $\begin{array}{c}\text { AHW } \\
(\%)\end{array}$ & $\begin{array}{c}\text { BHW } \\
(\%)\end{array}$ & $\begin{array}{c}\text { AHW } \\
(\%)\end{array}$ & $\begin{array}{l}\text { BHW } \\
(\%)\end{array}$ & $\begin{array}{l}\text { AHW } \\
(\%)\end{array}$ \\
\hline $\begin{array}{l}\text { Coagulase } \\
\text { negative } \\
\text { Staphylococci }\end{array}$ & $\begin{array}{c}25 \\
(100)\end{array}$ & $23(92)$ & $\begin{array}{c}25 \\
(100)\end{array}$ & $22(88)$ & $\begin{array}{c}25 \\
(100)\end{array}$ & $23(92)$ & $25(100)$ & $\begin{array}{c}22 \\
(88)\end{array}$ \\
\hline $\begin{array}{l}\text { Staphylococcus } \\
\text { aureus }\end{array}$ & $6(24)$ & $0(0.0)$ & $9(36)$ & $0(0.0)$ & $0(0.0)$ & $0(0.0)$ & $0(0.0)$ & $0(0.0)$ \\
\hline $\begin{array}{l}\text { Micrococcus } \\
\text { spp. }\end{array}$ & $23(92)$ & $21(84)$ & $22(88)$ & $22(88)$ & $24(96)$ & $23(92)$ & $24(96)$ & $\begin{array}{c}22 \\
(88)\end{array}$ \\
\hline Diphtheroids & $2(8)$ & $0(0.0)$ & $1(4)$ & $0(0.0)$ & $2(8)$ & $1(4)$ & $1(4)$ & $0(0.0)$ \\
\hline $\begin{array}{l}\text { Klebsiella } \\
\text { pneumoniae }\end{array}$ & $6(24)$ & $0(0.0)$ & $4(16)$ & $0(0.0)$ & $0(0.0)$ & $0(0.0)$ & $0(0.0)$ & $0(0.0)$ \\
\hline $\begin{array}{l}\text { Aerobic sporing } \\
\text { bacilli }(G B P)\end{array}$ & $4(16)$ & $0(0.0)$ & $3(12)$ & $1(4)$ & $7(20)$ & $0(0.0)$ & $3(12)$ & $0(0.0)$ \\
\hline E. coli & $1(4)$ & $0 .(0.0)$ & $0 .(0.0)$ & $0 .(0.0)$ & $0 .(0.0)$ & $0 .(0.0)$ & $0 .(0.0)$ & $0(0.0)$ \\
\hline
\end{tabular}

Table.2 Number and types of pathogens isolated /No. of HCWs

\begin{tabular}{|c|c|c|c|c|}
\hline $\begin{array}{c}\text { NAME OF } \\
\text { HEALTHCARE } \\
\text { WORKERS }\end{array}$ & $\begin{array}{c}\text { Staphylococcus } \\
\text { aureus (No. of } \\
\text { isolates / No. of } \\
\text { HCWs)) }\end{array}$ & $\begin{array}{l}\text { Staphylococcus } \\
\text { aureus (MRSA) } \\
\text { (No. of isolates / } \\
\text { No. of HCWs) }\end{array}$ & $\begin{array}{c}\text { Klebsiella } \\
\text { pneumoniae } \\
\text { (No. of isolates } \\
\text { / No. of HCWs) }\end{array}$ & $\begin{array}{c}\text { E. coli (No. of } \\
\text { isolates / No. } \\
\text { of HCWs)) }\end{array}$ \\
\hline STAFF NURSE & $4 / 3$ & $4 / 3$ & $4 / 2 *$ & 1/1 LT hand \\
\hline $\begin{array}{c}\text { SAFAI } \\
\text { KARMCHARI }\end{array}$ & $3 / 2$ & $\begin{array}{l}2 / 1 \mathrm{LT} \& \mathrm{RT} \\
\text { hand }\end{array}$ & $2 / 1 *$ & - \\
\hline $\begin{array}{c}\text { WARD } \\
\text { ATTENDENT }\end{array}$ & $3 / 3$ & - & $2 / 2$ & - \\
\hline TECHNICIANS & $4 / 2$ & - & $1 / 1$ (* $^{*}$ & - \\
\hline $\begin{array}{c}\text { Sr. } \\
\text { AAESTHESILOGIST }\end{array}$ & - & - & - & - \\
\hline SENIOR DOCTOR & - & - & - & - \\
\hline JUNIOR DOCTOR & $1 / 1$ & 1/1 LT hand & 1/1 RT hand* & - \\
\hline
\end{tabular}

Another HCWS other than S.aureus 
Table.3 Antibiotic sensitivity and resistant patterns on of isolates from health care workers

\begin{tabular}{|c|c|c|c|c|c|c|c|c|c|c|c|c|c|c|c|c|c|c|c|c|c|c|c|c|c|c|c|c|c|c|}
\hline $\begin{array}{ll}\text { NAME } & \text { OF } \\
\text { PATHOGES }\end{array}$ & $\mathbf{P}$ & & $\mathbf{O X}$ & & G & & CN & & VAN & & CIP & & CD & & $\mathbf{E}$ & & $\mathbf{L Z}$ & & NET & & AMP & & TE & & PM & & CO & & $\mathbf{A M}$ & \\
\hline & $\mathbf{S}$ & $\mathbf{R}$ & S & $\mathbf{R}$ & $\mathbf{S}$ & $\mathbf{R}$ & $\mathbf{S}$ & $\mathbf{R}$ & S & R & S & $\mathbf{R}$ & S & R & S & $\mathbf{R}$ & S & R & S & $\mathbf{R}$ & $\mathbf{S}$ & R & $\mathbf{S}$ & $\mathbf{R}$ & S & $\mathbf{R}$ & S & $\mathbf{R}$ & S & $\mathbf{R}$ \\
\hline $\begin{array}{l}\text { Staphylococcus } \\
\text { aureus }(\mathrm{N}=15)\end{array}$ & 6 & 9 & 8 & 7 & 9 & 6 & 12 & 3 & 15 & 0 & 12 & 3 & 15 & 0 & 11 & 4 & 15 & O & 15 & 0 & 8 & 7 & 11 & 4 & 8 & 7 & 0 & 15 & 9 & 6 \\
\hline $\begin{array}{l}\text { \%OF } \\
\text { SENSITIVITY/RE } \\
\text { SISTANTIVITY }\end{array}$ & $40 \%$ & $60 \%$ & $53.3 \%$ & $46.7 \%$ & $60 \%$ & $40 \%$ & $80 \%$ & $20 \%$ & $100 \%$ & $100 \%$ & $80 \%$ & $20 \%$ & $100 \%$ & $100 \%$ & $73.3 \%$ & $26.7 \%$ & $100 \%$ & $100 \%$ & $100 \%$ & $100 \%$ & $53.3 \%$ & $46.7 \%$ & $73.3 \%$ & $26.7 \%$ & $53.3 \%$ & $46.7 \%$ & $100 \%$ & $100 \%$ & $60 \%$ & $40 \%$ \\
\hline
\end{tabular}

Table.4 Antibiotic sensitivity and resistant patterns on of isolates from health care workers

\begin{tabular}{|c|c|c|c|c|c|c|c|c|c|c|c|c|c|c|c|c|c|c|c|c|c|c|c|c|c|c|c|c|c|c|c|c|c|c|c|c|c|c|}
\hline NAME OF & & IP & & G & & AK & C & AC & & TR & & IIP & AI & MC & & AT & IM & MP & $\mathbf{N E}$ & ET & CT & TX & c & C & c & B & $\mathrm{Cr}$ & PM & & CS & & CO & $T$ & TE & & TOB & & CX \\
\hline & $\mathbf{S}$ & $\mathbf{R}$ & $\mathbf{S}$ & $\mathbf{R}$ & $\mathbf{S}$ & $\mathbf{R}$ & $\mathbf{S}$ & $\mathbf{R}$ & $\mathbf{S}$ & $\mathbf{R}$ & $\mathbf{S}$ & $\mathbf{R}$ & $\mathbf{S}$ & $\mathbf{R}$ & $\mathbf{S}$ & $\mathbf{R}$ & $\mathbf{S}$ & $\mathbf{R}$ & $\mathbf{S}$ & $\mathbf{R}$ & $\mathbf{S}$ & $\mathbf{R}$ & $\mathbf{S}$ & $\mathbf{R}$ & $\mathrm{s}$ & $\mathbf{R}$ & $\mathbf{S}$ & $\mathbf{R}$ & $\mathrm{s}$ & $\mathbf{R}$ & $\mathbf{S}$ & $\mathbf{R}$ & $\mathbf{s}$ & $\mathbf{R}$ & $\mathbf{s}$ & $\mathbf{R}$ & $\mathrm{s}$ & $\mathbf{R}$ \\
\hline $\begin{array}{c}\text { Klebsiella } \\
\text { pneumoniae } \\
(\mathrm{N}=10)\end{array}$ & 0 & 10 & $\mathbf{0}$ & 10 & 0 & 10 & 0 & 10 & 0 & 10 & $\mathbf{0}$ & 10 & $\mathbf{0}$ & 10 & 0 & 10 & 10 & $\mathbf{0}$ & 1 & 9 & $\mathbf{0}$ & 10 & 1 & 9 & 0 & 10 & 0 & 10 & $\mathbf{0}$ & 10 & 0 & 10 & 0 & 10 & 0 & 10 & 0 & 10 \\
\hline $\begin{array}{c}\% \text { OF } \\
\text { SENSITIVITY/ } \\
\text { RESISTANTIVI } \\
\text { TY }\end{array}$ & $100 \%$ & $100 \%$ & $100^{\circ}$ & $\% 100 \%$ & $100 \%$ & $\% 100 \%$ & $100 \%$ & $100 \%$ & $100 \%$ & $\% 100 \%$ & $100 \%$ & $100 \%$ & $\% 100 \%$ & $100 \%$ & $\% 100 \%$ & $\% 100 \%$ & $100 \%$ & $100 \%$ & c $10 \%$ & $90 \%$ & $100 \%$ & $100 \%$ & $10 \%$ & $90 \%$ & $100 \%$ & $100 \%$ & $100 \%$ & $100 \%$ & $\% 100 \%$ & $\% 100 \%$ & $100 \%$ & $\% 100 \%$ & $100 \%$ & $100 \%$ & $100 \%$ & $\% 100 \%$ & $\% 100 \%$ & $\% 100 \%$ \\
\hline $\begin{array}{l}\text { Escherichia coli } \\
\quad(\mathbf{N}=\mathbf{1})\end{array}$ & 1 & 0 & 1 & $\mathbf{0}$ & 1 & 0 & 1 & $\mathbf{0}$ & 1 & $\mathbf{0}$ & 1 & $\mathbf{0}$ & $\mathbf{0}$ & 1 & 1 & $\mathbf{0}$ & 1 & $\mathbf{0}$ & $\mathbf{0}$ & 1 & 1 & $\mathbf{0}$ & $\mathbf{0}$ & 1 & 0 & 1 & 1 & $\mathbf{0}$ & $\mathbf{0}$ & 1 & $\mathbf{0}$ & 1 & $\mathbf{0}$ & 1 & 1 & 0 & $\mathbf{0}$ & 1 \\
\hline $\begin{array}{c}\% \text { OF } \\
\text { SENSITIVITY/ } \\
\text { RESISTANTIVI } \\
\text { TY }\end{array}$ & $100^{\circ}$ & $100 \%$ & $100^{\circ}$ & $\% 100 \%$ & $100 \%$ & $\% 100 \%$ & $100 \%$ & $100 \%$ & $100 \%$ & $\% 100 \%$ & $100 \%$ & $100 \%$ & $\% 100 \%$ & $100 \%$ & $\% 100 \%$ & $100 \%$ & $100 \%$ & $100 \%$ & $7100 \%$ & $100 \%$ & $100 \%$ & $100 \%$ & $100 \%$ & $100 \%$ & $\% 100 \%$ & $100 \%$ & $100 \%$ & $100 \%$ & $7100 \%$ & $\% 100 \%$ & $100 \%$ & $\% 100 \%$ & $100 \%$ & $6100 \%$ & $7100 \%$ & $\% 100 \%$ & $\% 100 \%$ & $\% 100 \%$ \\
\hline
\end{tabular}


This study also similar to study done by Pant et al., ${ }^{(14)}$ in which the Gram positive cocci were the most predominant ones among the bacterial isolates from the environment have Staphylococcus aureus $10 \%$ in their hands, Escherichia coli 8\%, Klebsiella spps. $10.2 \%$ and $5.7 \%$ carrier isolates of $S$. aureus were found to be Methicillin resistant. In the present study $33.33 \%$ nurses s were having Klebsiella pneumoniae, $50 \%$ nurses were having $S$. aureus and $4 \%$ from total HCWs having E. coli. However Casewell et al., (6) who has reported Klebsiella pneumoniae 12\% and Staph aureus $30 \%$ isolates from nurses hands.

It was observe that most of gram negative bacteria were sensitive to Imipenem and lesser extent with Netilmicin and Chloramphenicol and most of gram positive bacterial strains sensitive were Linezolid and Cefoxitin. This variations may be due to use of variety of antiseptic solutions, soaps and methods of hand washing.

In conclusion, this study provides the prevalence of bacteria on hands of healthcare providers before hand washing mainly those involve in close patients care areas they may becomes a source of transmitting HAI in wards. Although no bacteria found after hand wash and from Senior Doctors. We observed that maintaining self hygiene and proper hand washing reduces the contamination and HAI. HCWs were harbouring the abundant multidrug resistant Gram positive pathogens more than Gram negative pathogens.

This study indicates that the hand hygiene practice results in a decrease infection rate and need for sensitization and training to HCWs for improve knowledge about infection control policies implication to intervene and control nosocomial infection and minimize the MRSA and multidrug resistant bacterial outbreaks.
Further suggest that more assessing of relationship among clinical samples, environmental samples and hand samples with randomized and programmed sampling should be done.

\section{References}

1. WHO guidelines on hand hygiene in health care (advanced draft). a summary. Geneva: World Health Organization; 2005, 2009 14-6

2. Babb JR, Davies JG and Ayliffe GA. Contamination of protective clothing and nurses' uniforms in an isolation ward. Journal of Hospital Infection 1983; 4: 149-57.

3. Doebbling B.N., Stanley G.L., Sheetz G.T., Pfaller M.A. Comparative efficacy of alternate hand washing agents in reducing nosocomial infections in intensive care units. $\mathrm{N}$ Eng J Med. 1992 Jul 9; 327(2): 88-93.

4. Larson E.L.: APIC Guidelines for hand washing and hand antisepsis. Am J Infect Control. 1995 Aug; 23(4): 251-69

5. Centre for Disease Control (CDC): Isolation techniques for use in hospitals, 2nd ed. Washington, DC: Government Printing Office, 1983; 13

6. Case well M. Phillipos I. hands as a route of transmission of Klebsiella species Br Med j.1977 Nov 19; 2(6098): 1315-7.

7. Mangaram AJ, Horan TC, Peason ML et al.,: Guidelines for prevention of surgical site infection. INFECTION CONTROL AND HOSPITAL EPIDEMIOLOGY 1999 Vol. 20 No. $4: 247$

8. $\mathrm{Br} \mathrm{J}$ Nurse. Medicine, Section of Ageing and Health, Ninewells Hospital, Dundee. 2002 Sep 12-25; 11 (16): 1072, 1074-7

9. Bauer A.W., Kirby W.M.M., Sherris J.C., Truck M. Antibiotic susceptibility 
testing by a standardized single disk method. Am J Clin Path. 1966; 45: 493 496.

10. R. Panhotra, Anil K. Saxena, Abdulrahman S. Al-Mulhim, Contamination of patients' files in intensive care units: An indication of strict handwashing after entering case notes 2005 Sep 33 (7): 398-401.

11. P.GaspardE. Eschbach D. Gunther, S. Gayet, X. Bertrand, D. Talon Meticillinresistant Staphylococcus aureus contamination of healthcare workers' uniforms in long-term care facilities 2009 Feb 71(2): 170-175.
12. Wong $\mathrm{D}$, Nye $\mathrm{K}$ and Hollis $\mathrm{PB}$. Microbial flora on doctors' white coats. British Medical Journal 1991; 303: 1602-4.

13. A.R. Gupta Lt. Col, Lt. Col. (Mrs.) N. Kaul Col. V. Saraswat. Brig. T. Prabhakar VSM In an ICU set up and effect of barrier nursing on the existing profile. Indian J Anaesth (2005): 49 [1]; 31-26.

14. Pant J, Rai SK, Singh A, Lekhak B, Shakya B, and Ghimire G Nepal Medical College journal: NMCJ 2006 Sep.8 (3): 194-9.

\section{How to cite this article:}

Ranweer, Geeta Parihar, Nirwan Prem Singh and Chandwani Jyotsna. 2019. Prevalence of Microbes on Hands of Health Care Workers in Surgical Intensive Care Unit at Tertiary Care Hospital. Int.J.Curr.Microbiol.App.Sci. 8(03): 1105-1111. doi: https://doi.org/10.20546/ijcmas.2019.803.133 